\title{
O papel da grande mineração e sua interação com a dinâmica urbana em uma região de fronteira na Amazônia
}

The role of large-scale mining and its interaction with urban dynamics in a frontier region in the Amazon

\begin{abstract}
This article deals with particularities of the urbanization process associated to the mining dynamics, which articulate directly the extraction territories to the global accumulation circuits. On the Amazon frontier, the forms of capital operationalization, altered the urban structuring, the urban-rural relationship and caused an enormous impact on the nature and on the most vulnerable sections of the population. The analysis is based on the Lefebvrian derivation of extended urbanization and on the notion of levels of social reality; has the objective of exploring the relational connections of the urban with the global and local levels and allow the construction of parallels between the iron ore extraction at the Serra dos Carajás and the gold exploration, at the Vale do Husco, northern region Chile. We observe an urban dynamic governed by the global sphere, and parallel processes, embryos of a new urban matrix, in the local sphere, centered on the reproduction of life and the construction of citizenship.
\end{abstract}

\section{Keywords}

Parauapebas; Southeast of Pará; mining; extended urbanization.

JEL Codes R230; R510.
Ana Carolina Campos de Melo

Universidade Federal do Pará

Ana Cláudia Duarte Cardoso

Universidade Federal do Pará

\section{Resumo}

Este artigo aborda particularidades do processo de urbanização associadas às dinâmicas de mineração, que articulam diretamente os territórios de extração aos circuitos globais de acumulação. $\mathrm{Na}$ fronteira amazônica, as formas de operacionalização do capital alteraram a estruturação urbana, o relacionamento urbano-rural e causaram enorme impacto sobre a natureza e sobre as camadas mais vulneráveis da população. A análise baseia-se na derivação lefebvriana de urbanização extensiva e na noção de niveis da realidade social; tem o objetivo de explorar as conexões relacionais do urbano com os niveis global e local e permitir a construção de paralelos entre a extração de minério de ferro na Serra dos Carajás e a exploração de ouro, na região do Vale do Huasco, norte do Chile. Observa-se uma dinâmica urbana regida pela esfera global, e processos paralelos, embriões de uma nova matriz urbana, na esfera local, centrados na reprodução da vida e na construção da cidadania.

\section{Palavras-chave}

Parauapebas; Sudeste do Pará; mineração; urbanização extensiva.

Códigos JEL $R 230 ; R 510$. 


\section{Em busca de uma leitura comparativa do urbano}

Este artigo busca estabelecer paralelos entre os processos em curso na região da Serra de Carajás, no Estado do Pará, com as análises disponíveis na literatura que abordam as conexões entre a ação das indústrias de extração de recursos e o processo de urbanização na América Latina. $\bigcirc$ texto assume como principais contribuições dessa literatura os estudos de Martín Arboleda (2015a; 2015b) sobre cidades e núcleos mineradores localizados no Chile e na Colômbia, que evidenciam como esses espaços se constituem em expressões de um processo típico de urbanização resultante da demanda internacional por matérias-primas. O caso do Vale do Huasco, no norte do Chile, mostra como a atuação de uma empresa de mineração transnacional, a Barrick Gold Corporation, resultou em uma problemática expansão do espaço urbano em Vallenar, cidade impactada pela ação da empresa. O projeto Pascua Lama, iniciado ainda na década de 1990, comandado por financistas, gestores corporativos internacionais e com investimento estimado em U\$ 5 bilhões de dólares (Fontevecchia, 2013) foi paralisado em 2013 pela corte chilena, devido ao descumprimento das medidas de mitigação de impactos ambientais. Empreendimentos mineradores desse porte comumente são marcados por transformações intensivas do ambiente construído, práticas de pilhagem socioambiental e, no limite, pela formação e intensificação de espaços de desigualdade (Arboleda, 2015a; Brenner; Schmid, 2014).

Por meio da narrativa dos acontecimentos observados nas últimas décadas no Sudeste Paraense, o artigo também procura contribuir para o debate contemporâneo sobre urbanização (Monte-Mór, 1994, 2015; Brenner, 2014; Peck, 2014). Nessa via, busca ilustrar pontos de convergências com abordagens globalmente abrangentes, como a corrente do urbanismo planetário (Brenner, 2013, 2014; Brenner; Schmid, 2015; Arboleda, 2015a, 2015b). O artigo também dialoga com a proposta de articulação dialética entre urbano, rural e natural proposta por Monte-Mór (2015), que a partir de uma revisão da forma como urbanização, desenvolvimento e sustentabilidade são compreendidos, propõe a articulação entre urbanização e naturalização extensivas. No estudo de caso adotado, observa-se um processo de urbanização orientado por uma economia extrativa cada vez mais conectada aos circuitos globais de troca, e, portanto, responsiva às teses sobre urbanização planetária e/ ou extensiva. Para evidenciar esse proces- 
so e criar a possibilidade de comparação entre estudos de caso, recorreu-se ao pensamento de Henri Lefebvre (2008 [1970]) e exploraram-se as conexões entre os múltiplos níveis da realidade social. A análise dialética dos níveis local, urbano e global mostra que a globalização do capital tende a sujeitar cada vez mais a vida diária aos imperativos da economia global por meio de um processo urbano extensivo (Arboleda, 2015a, 2015b; Monte-Mór, 1994).

Ainda que os processos de modernização alavancados por atividades primárias e/ou grandes projetos de infraestrutura de forte impacto sobre a vida da população local não sejam novidades no país e, sobretudo, na Amazônia Brasileira, há diferenças entre os processos observados nas décadas anteriores e as atuais formas de extração de recursos, implantação de instalações logísticas e de produção e circulação de energia. Tais diferenças estão relacionadas à escala e ao ritmo das transformações sociais e ambientais observadas nas experiências recentes. Vide os alertas de impacto da instalação da hidrelétrica de Belo Monte (Fearnside, 2006) e o colapso da barragem de Mariana, considerado o pior desastre ambiental e do setor de mineração da história do Brasil (Gonzales, 2016).

No sudeste do Pará, essa articulação resultou em um movimento de transbordamento do capital financeiro internacional para o processo de urbanização, envolvendo grandes proprietários de terra da região amazônica (Melo, 2015). Sustenta-se a hipótese de que as formas contemporâneas de desenvolvimento do capital na fronteira amazônica, assim como no caso chileno, transformaram a escala e intensidade de produção do espaço, estendendo o tecido urbano sobre áreas anteriormente isoladas ou pouco integradas ao capitalismo global, com impacto tanto sobre o ambiente construído (edifícios, infraestrutura) quanto sobre a esfera representacional e subjetiva (práticas e modos de vida) (Arboleda, 2015a).

O cenário da Serra dos Carajás, região mineradora gestada no contexto dos grandes projetos de investimento desenvolvidos na Amazônia, durante a segunda metade do século XX, é mobilizado para ilustrar as amplas mudanças nas dinâmicas da grande indústria de mineração e seus efeitos mais imediatos sobre a região de extração, muito semelhante ao que aconteceu em Pascua Lama, nos Andes chilenos, e em outras cidades do Sul Global. Segundo Arboleda (2015b), os espaços de extração de recursos naturais têm se constituído, não só como uma das principais forças motrizes da urbanização extensiva, mas também como expressões morfológicas 
particulares deste processo. Em consonância com casos latino-americanos (Arboleda, 2015b), Parauapebas revela claramente a inserção de um contexto não metropolitano em uma dinâmica de urbanização acelerada, como consequência da intensificação das conexões entre a esfera produtiva e o circuito financeiro (Harvey, 2010 [1980]; Brandão, 2008; Fix, 2011), com efeitos diretos sobre a vida diária dos seus habitantes.

\section{Níveis da realidade social e a urbanização extensiva na fronteira amazônica}

Em sua obra seminal A Revolução Urbana (2008 [1970]), Henri Lefebvre concebe a totalidade social como o resultado das múltiplas inter-relações entre níveis no eixo espaço-temporal, um todo formado pela interação entre um nível global (G); um nível misto (M); e um nível privado (P). Em detalhe, um nível global $(G)$ e mais abstrato, que se projeta sobre o espaço por um sistema de referências gerais, que busca em sua permanente contradição a homogeneização e universalização do espaço social; um nível misto (M), intermediário e especificamente urbano, constituído tanto por elementos prático-sensíveis (a ordem próxima), quanto por interações e representações mais amplas e abstratas (a ordem distante); e por último, um nível privado (P), identificado aqui como o nível local, que engloba a esfera da vida cotidiana, isto é, as relações de vizinhança e de moradia, concebida como a escala mais imediata das relações sociais manifestas no "chão da vida".

Lefebvre, imerso nos conflitos da sociedade industrial, buscava uma interpretação teórica da realidade social em sua totalidade, para além do "mundo das aparências". É neste sentido que a compreensão relacional de níveis e dimensões busca superar a leitura fragmentária do urbano, típica das ciências parcelares ${ }^{1}$, que dificultam a realização de estudos comparativos e obscurecem as possibilidades de investigação de padrões e tendências urbanas, condicionadas por mudanças estruturais no processo de desenvolvimento capitalista (Peck, 2014). Nesse sentido, o urbano é entendido como um processo de abrangência global e socialmente contraditório (Brenner; Schimdt, 2015), que se materializa a partir de diversas

1 Tais como o urbanismo ou o planejamento urbano, que tendem a tomar a realidade por aquelas das suas camadas, que são compatíveis com as ferramentas de análise de que tais ciências dispõem. 
morfologias socioespaciais, resultantes de condições específicas de origem histórica, econômica e social.

A investigação das inter-relações entre os níveis da vida cotidiana, urbana e global, busca estabelecer um quadro explicativo sobre a rápida urbanização em locais de extração de recursos, onde grandes mudanças têm sido observadas, tanto em termos de transformações no espaço concreto, como na esfera mais subjetiva (Arboleda, 2015a), com a penetração de padrões de consumo modernos e da dissolução de arranjos socioeconômicos tradicionais. Por esse motivo, as análises apresentadas neste artigo relacionam a abordagem lefebvriana de níveis aos estudos voltados para a compreensão das especificidades dos países periféricos (Santos, 2000 [1974]).

Nas últimas décadas, Parauapebas expandiu em quase 10 vezes sua malha urbana ${ }^{2}$ em comparação com seu núcleo inicial. Este texto explora evidências de que tal movimento foi alavancado pelo estreitamento das conexões entre o capital financeiro global e agentes intermediários e locais. Destaca-se o modo como os grandes proprietários de terra diversificam suas atividades em estratégias capitalistas mais sofisticadas, a exemplo da transformação de bens imobiliários em ativos financeiros, ao mesmo tempo em que perpetuam velhas práticas vinculadas ao capital extrativo-mercantil, marcadas por ações de violência e pilhagem socioambiental. Em suma, observa-se a manifestação do fenômeno da urbanização extensiva apresentado por Monte-Mór (1994), em convergência com a tese da urbanização planetária de Brenner (2014) em um contexto periférico, em que tendem a se amplificar as contradições da urbanização capitalista.

A noção de urbanização extensiva (Monte-Mór, 1994) deriva da hipótese presciente de Henri Lefebvre sobre "a urbanização completa da sociedade", antecedida por um movimento dicotômico de implosão (concentração, aglomeração das práticas urbanas) e explosão (extensão do tecido urbano e intensificação das conexões entre os espaços) da cidade. Logo, o urbano não pode mais ser reduzido a um objeto claramente delimitado ("a cidade"); deve ser compreendido como um fenômeno multidimensional, que transcende qualquer dicotomia entre campo e cidade. De modo simplificado, três dimensões se destacam: a da projeção das relações a nível global sobre o espaço, a dos conflitos e das coalizões entre os diversos agentes no nível intermediário (gestores, corporações, proprietários fun2 Estrutura urbana formada por ruas, avenidas, rodovias, prédios, espaços públicos e elementos urbanos em geral que constituem tecido físico da cidade. 
diários, grupos socialmente excluídos) e a da prática urbana diária, ou das relações concretas nem sempre perceptíveis e apreendidas pelos atores sociais que se articulam a essas dimensões (Lefebvre, 2008 [1970]).

A urbanização contemporânea tem produzido novas e diversas geografias, que refletem a tendência inerente ao capitalismo de se desenvolver de forma desigual, com expressão mais intensa no território, sobretudo em espaços de extração de recursos, dos desequilíbrios entre níveis da realidade social (Lefebvre, 2008 [1970]; Brenner, 2013; Brandão, 2008). Sob esta perspectiva, a velha dicotomia rural-urbano não é mais suficiente para explicar o fenômeno urbano, diante da expansão contínua da produção imobiliária (construção de shoppings, condomínios, conjuntos habitacionais, grandes lojas de varejo, etc.) e das grandes inversões de capital (construção de estradas, portos, ferrovias, hidrelétricas, etc.), para além das áreas metropolitanas, em direção às diversas periferias, contínuas ou descontínuas ${ }^{3}$.

O volume de recursos e o ritmo de transformações associadas a projetos de investimentos conectados ao mercado globalizado, ao invés de reduzir, tem acentuado o contraste entre espaços de riqueza, crescimento e privilégio, e espaços de pobreza, declínio e exclusão (Brenner; Schmid, 2015). $\mathrm{Na}$ fronteira capitalista, este processo torna-se mais evidente na medida em que ocorre a abertura do território ao capital. Por um lado, os atores situados nos níveis global e urbano conseguem criar arranjos produtivos de matriz industrial e se articular aos diversos espaços de operação do capital, enquanto por outro lado, uma significativa parte da população, não absorvida pela economia formal, integra-se à economia urbana por meio de práticas alternativas. Tais práticas, consideradas informais pela matriz hegemônica, incluem atividades de baixa intensidade de capital e intensivas em força de trabalho (Santos, 2008 [1974]). Contradições desse tipo podem ser claramente observadas mesmo em projetos socioeconômicos em curso no Sudeste Paraense, apoiados pela Vale, como é o caso do Projeto Jaborandi ${ }^{4}$.

3 Em fases anteriores do capitalismo, as periferias eram inseridas em contextos metropolitanos, fossem próximas ou distantes das áreas centrais, a depender da presença de infraestrutura, dos serviços urbanos e da qualidade de vida em geral. O processo em curso no Sudeste Paraense demonstra que as sedes de municípios mineradores se constituem em periferias de metrópoles distantes, nacionais ou globais, onde são concentrados os benefícios de tais projetos, e onde ocorre a divisão do trabalho associada ao insumo extraído.

4 O Projeto Jaborandi é uma parceria entre Vale S.A. e Instituto Chico Mendes de Conservação da Biodiversidade (ICMBio). O objetivo do projeto é incentivar e preservar a atividade de coleta de sementes nativas e de folhas de Jaborandi na região, através do treinamento técnico 
Do ponto de vista da atração de grandes fluxos de capital e da sinergia intrinsecamente urbana gerada pela grande mineração (Monte-Mór, 2001), poderíamos supor a criação de uma condição consistente para o surgimento de diversas oportunidades econômicas na região (Jacobs, 2001). No entanto, a grande mineração em inserção periférica, contraditoriamente, intensifica as condições de desigualdade socioespaciais, uma vez que sua ação seletiva e concentrada produz poucas alternativas de transbordamento e apropriação local dos benefícios produzidos pela extração de recursos. O próprio número de empregos gerados é limitado, em contraste com o contingente populacional que é atraído para o território. Além disso, a automatização cada vez maior do processo de extração de minério exige certo grau de qualificação técnica dos operadores da mina, criando barreiras de entrada para a absorção da mão de obra local. A presença da empresa no território, contudo, ampliou oportunidades para os agentes que detêm o controle da terra e atraiu sucessivos contingentes populacionais, viabilizando sinergias entre investimentos na extração mineral e na produção de cidade, segundo uma visão hegemônica e exógena.

Ao explorar paralelos entre a narrativa e a abordagem metodológica de Martín Arboleda (2015a, 2015b) para o Vale do Huasco, no norte do Chile, e o estudo sobre a região da Serra de Carajás, este texto procura mostrar como as geografias de extração contemporâneas evidenciam interações contraditórias e complexas entre os três níveis da realidade social. Isto é, se de um lado, as conexões diretas entre o circuito global de acumulação e os locais de extração têm promovido uma aproximação entre atores globais, intermediários e locais; por outro, a projeção dessas relações no espaço concreto reflete o descolamento entre os interesses dos atores envolvidos com o grande capital em nível global e as demandas mais imediatas da população, principalmente as camadas mais vulneráveis e dependentes de acesso à terra, à água e à biodiversidade. Isso tem a ver, como Harvey (2013) afirma, com a forma como o capital passa a ser alocado na terra, quando os nexos entre o capital financeiro e o uso da terra se intensificam, passando a moldar não apenas os investimentos privados, mas a própria forma de estruturação geográfica da produção,

da mão de obra. No entanto, o projeto perpetua a posição dos coletores como produtores de matéria-prima na medida em que visa exclusivamente à manutenção da atividade de extração de sementes, sem que haja o interesse de incorporar inovações tecnológicas e administrativas ou promover a diversificações da cadeia produtiva do produto. 
das divisões de trabalho e, no limite, da dinâmica dos espaços de reprodução da vida diária.

\section{A grande mineração e o nível global: conexões entre a Barrick Gold e a Vale S.A.}

A Companhia Vale do Rio Doce (CVRD) foi fundada na década de 1940, como resultado do chamado "Acordo de Washington", que, entre uma série de resoluções, instituiu a criação de uma empresa estatal para explorar, comercializar e distribuir minério de ferro, com o objetivo de abastecer a indústria bélica britânica e americana. Tal fato indica que desde a sua origem, a hoje multinacional, Vale S.A ${ }^{5}$, teve sua atuação ligada ao mercado externo.

Na década de 1950, a ampliação do número de países produtores de minério de ferro aumentou a competitividade entre as empresas e reduziu o preço do minério de ferro, um estímulo para a CVRD buscar novos mercados consumidores, como Japão, Alemanha Ocidental e Canadá. No período entre 1961 e1967, o Japão passou a representar algo entre 7,97\% a $22,76 \%$ das exportações de minério de ferro da CVRD e ocupou a posição de segundo maior destino das exportações da mineradora brasileira. A partir desse período, o regime militar foi em grande parte responsável por posicionar o Brasil na divisão internacional do trabalho como fornecedor de matérias-primas. Neste contexto de fortalecimento da produção de matérias-primas, alavancada por grandes projetos de investimento com foco no crescimento econômico do país, foi gestado o projeto de exploração das minas de ferro da Serra dos Carajás, no Sudeste do Pará, culminando com a criação do Programa Grande Carajás (PGC). Em 1985, após duas décadas de negociações político-econômicas, entrou em operação o Complexo de Carajás, um conjunto formado por mina, instalações de beneficiamento, company town, ferrovia, estradas e porto. Principal projeto do setor mineral empreendido no contexto dos Grandes Projetos, a implantação da mineradora constituía mais do que uma atividade produtiva, configurava uma estratégia para o fortalecimento do governo federal na região. A implantação do PGC retirava do governo estadual o controle 5 A privatização da CVRD ocorreu em maio de 1997, quando a empresa passou a ser chamada de Vale S.A. 
sobre as terras da região da Serra dos Carajás e o transferia para a CVRD, ligada diretamente ao governo federal. Este arranjo foi viabilizado através da delimitação de uma enorme área de preservação ecológica (instituída como floresta nacional, em 1997) e da projeção da construção de uma estrada próxima aos limites da reserva, estratégia que automaticamente transferia para o governo federal o controle sobre as faixas de terra próximas à rodovia planejada (Bunker, 2007a), e evitava outras solicitações quanto à exploração do minério e uso da terra, ao mesmo tempo, em que afastava indígenas, comunidades tradicionais, camponeses e pequenos agricultores que habitavam o território.

A extração de minério em Carajás tinha, em grande medida, relação com a demanda por ferro e aço das indústrias brasileiras e internacionais, e também correspondia a uma forte dependência financeira do país em relação ao capital externo, tanto de investimentos voltados diretamente para extração de minério em Carajás, quanto para o desenvolvimento industrial da região Sudeste do país (Bunker, 2007a). Apesar da relativa influência do capital estrangeiro e da controversa atuação do Estado, o contexto de extração de recursos na região da Serra do Carajás difere bastante daquele observado nos Andes chilenos. No Chile, desde a década de 1970, quando o regime ditatorial de Pinochet assumiu o poder, diversas medidas neoliberais foram postas em vigor, como a redução da participação do Estado na economia, abertura aos fluxos de capital externo, liberalização do mercado financeiro, privatização de empresas do setor público e ampliação da participação de empresas e corporações privadas e estrangeiras na economia nacional. No Brasil, medidas no mesmo sentido passaram a vigorar somente na década de 1990.

Nesta via, a atuação da Barrick Gold Corporation, no norte do Chile, oferece um importante laboratório das formas de atuação de uma empresa transnacional de extração de recursos, fortemente integrada à dinâmica financeira com apoio do Estado, em um contexto em que a iniciativa privada e o capital global financeirizado operam livremente, com antecedência de pelo menos duas décadas em comparação com o Vale S.A., no Sudeste Paraense. Apesar de todas as premissas da atuação do governo federal, durante o período em que a empresa mineradora brasileira foi estatal, investimentos em outras áreas também foram realizados, como é o caso da requalificação urbanística da ocupação informal no núcleo pioneiro e da construção do Núcleo Urbano de Carajás (NUC). 
Após a privatização, a Vale S.A. se tornou uma das empresas mais importantes da indústria de minério de ferro e uma das principais forças motrizes da economia exportadora amazônica, dependente de commodities como a soja, o gado e o minério. Durante as últimas duas décadas, o mercado asiático emergiu como principal consumidor de matérias-primas produzidas por economias orientadas à exportação de commodities, como a do Brasil. Neste período, a Vale apresentou uma produção crescente, com resultado de 31,8 milhões de toneladas de minério de ferro, em 1989; 45,8, em 1998; 97,3, em 2008; atingindo 119,7 milhões de toneladas, em 2014, com uma expansão de $276 \%$ nos últimos 26 anos.

Números extraordinários também são uma realidade para Barrick Gold, a empresa originalmente canadense que opera em cinco continentes possui 26 minas de ouro e, assim como a Vale S.A., é uma das empresas mais importantes de seu segmento de mineração, a extração de ouro. Em 2012, extraiu 7,42 milhões de onças de ouro e alcançou um fluxo de US \$ 4,2 bilhões de caixa operacional em 2013, tornando-se líder mundial na produção de ouro (Arboleda, 2015a). Outro importante paralelo entre as empresas tem sido combinar a produção física com a sofisticação de suas estratégias financeiras. A extração de recursos naturais não era a única fonte de capital da antiga CVRD, acompanhando o movimento das indústrias de mineração em geral. Em 1988, ainda na época da empresa estatal, a CVRD vendia sua produção de minério de ferro no mercado futuro. Após a privatização, as ações da Vale S.A. passaram a ser comercializadas na Bolsa de Valores de Nova York (NYMEX). Em 2007, as ações da mineradora brasileira foram as mais negociadas entre as empresas estrangeiras, atingindo um giro médio diário de US\$725,5 milhões (Coelho, 2014). As ações da Barrick Gold também são negociadas na Bolsa de Valores de Nova York e na Bolsa de Valores de Toronto. Em 2009, a empresa emitiu US \$ 3 bilhões em ações e em 2013 alcançou US \$ 4 bilhões em emissões, as duas maiores ofertas de ações da história da Bolsa de Valores de Toronto (Arboleda, 2015a).

Em Parauapebas, as dinâmicas globais ligadas ao mercado financeiro extrapolaram a exportação de commodities e passaram a moldar a forma como o espaço urbano é produzido. Nos últimos anos, bancos e securitizadoras internacionais têm se aliado a atores regionais e intensificado o processo de urbanização extensiva deflagrado durante o boom das commodities por meio da produção excepcional de loteamentos urbanizados. 
Tal fato foi viabilizado com a entrada de capital oriundo de fundos de investimentos internacionais.

Assim, os fluxos financeiros globais conectam os excedentes de capital a locais anteriormente isolados, mas importantes no que se refere à concentração de recursos naturais. Essas áreas absorvem os excedentes de capital no ambiente construído, seja através de novas instalações logísticas, seja por meio da produção de shoppings centers, conjuntos habitacionais e de outras "fórmulas globais". Segundo Arboleda (2015a), os investimentos em capital intensivo mobilizados pela mineração não seriam viáveis sem convergência de interesses entre os produtores físicos e o sistema de crédito:

(...) Ao longo deste processo, bolsas de valores, comerciantes, investidores institucionais e tecnocratas se entrelaçam nas relações de transformação mútua de geografias remotas que se tornam rapidamente urbanizadas. (Arboleda, 2015a, p. 6).

Arboleda (2015a) argumenta que a inserção de lógicas financeiras na governança corporativa da Barrick Gold também pode ser observada em sua orientação para elevar a remuneração de seus acionistas em resposta às pressões exercidas por investidores. Em períodos de recessão, como o que está em curso desde 2011, os investidores pressionam a gestão a abandonar estratégias expansionistas, colocando à venda uma série de ativos destas empresas. Por meio do programa de desinvestimentos, a Vale S.A. vendeu seu capital investido na Usiminas (2,93\% do total); seus ativos na International Metals Reclamation Company (Inmetco) (US\$ 38,6 milhões), e na Jinco Nonferrous Metals Co. Ltd. (Jinco) (US\$ 6,5 milhões); 76,7\% de sua participação na Inco Advanced Technology Materials (Dalian) e 77\% da Inco Advanced Technology Materials (Shenyang), totalizando entre 2009 e 2010 uma arrecadação de US\$ 100 milhões (Coelho, 2014). Essa mudança nas estratégias das empresas de extração de recursos revela uma abordagem mais conservadora na alocação de capital, que tem sido uma tendência geral entre os produtores de matérias-primas (Arboleda, 2015a). As estruturas de poder internas se alteram, com objetivo de fazer convergir os interesses de especuladores de commodities, gestores corporativos, acionistas da empresa e do Estado (Coelho, 2014).

Em ambos os casos também soa marcante a atuação do Estado como uma espécie de facilitador da expansão da produção física das indústrias de extração. No caso chileno e de sua larga expertise no âmbito das reformas neoliberais, observam-se como as medidas econômicas implemen- 
tadas pelo governo alimentaram a intensificação de investimentos e um aumento na entrada de fluxos de capital estrangeiro, criando um cenário favorável para a inserção de grandes empresas de mineração na economia chilena, como a Barrick Gold. No caso brasileiro, o Estado, além de fomentar a Vale S.A. com participação acionária, liberou grandes financiamentos para a empresa. Em 2014, o Banco Nacional de Desenvolvimento (BNDES) aprovou para a empresa mineradora um financiamento de $\mathrm{R} \$$ 6,2 bilhões, para realização de investimentos em infraestrutura, segundo Coelho (2014, p. 24):

Nesta conjunção de interesses, os especuladores lucram com a participação da Vale no mercado de bens futuros, os acionistas com a valorização dos títulos da empresa, e o governo federal com o aumento da arrecadação e com o equilíbrio da balança comercial.

Para Arboleda (2015a), esse processo de financeirização da extração de recursos naturais ilustra a ideia de níveis lefebvriana em sua totalidade. Isto é, não como um "fato econômico isolado, mas como um processo mais amplo de financeirização do capitalismo" (Ibidem, p. 8), que passa a envolver não apenas o Estado, mas os agentes intermediários, a exemplo dos grandes proprietários de terras e de empresários regionais, no Sudeste do Pará. A construção teórica de níveis, por ser relacional, possibilita uma interpretação dos fatos observados em ambos os contextos de extração como um todo articulado e não como estudos de caso aparentemente separados e independentes, ainda que constituam realidades históricas internamente diferenciadas.

\section{0 nível intermediário: o boom da mineração e as dinâmicas urbanas}

Em um contexto de crescente demanda e flutuação dos preços no mercado internacional, a Vale S.A. tornou-se uma das empresas mais importantes na indústria de minério de ferro. Antes da privatização, a corporação formava um conglomerado de 30 empresas, com lucro líquido entre de US\$300 e US\$ 700 milhões, contrariando o argumento de que a empresa estatal era deficitária quando estatal (Coelho, 2014). A privatização da CVRD, em 1997, fez parte de um processo mais amplo do capitalismo, apoiado no fortalecimento da doutrina neoliberal na década de 1980 e na dissemina- 
ção para o resto do mundo das recomendações de agências internacionais (BIRD, FMI), as quais preconizavam a redução das atribuições do Estado em favor do livre mercado, de acordo com um receituário de reformas políticas e econômicas direcionadas, particularmente, aos países do Sul Global.

A experiência chilena mostra que as estratégias neoliberais, elaboradas para estimular a atração de grandes fluxos de capital estrangeiro, criam as condições para o aumento desmesurado da produção física, alimentam os delírios especulativos das novas frentes de expansão e conectam esse movimento à circulação de capital em âmbito global, através da desregulamentação financeira. No limite, lançam as bases para que as grandes empresas de extração de recursos se instalem em seus territórios, protegidas por um marco político institucional que tende a beneficiar os projetos de investimento de multinacionais, em detrimento do desenvolvimento das indústrias nacionais e dos interesses coletivos.

A privatização da Vale coincidiu com o período de valorização das commodities, quando o mercado asiático, com destaque para a China, emergiu como principal consumidor de matérias-primas. A demanda chinesa impulsionou uma forte expansão da indústria de extração de recursos e intensificou a concorrência entre Estados, corporações privadas e elites locais pelo controle da terra e dos recursos naturais (Harvey, 2011 [2010]). A nova escala de investimentos e o novo ritmo de produção de minério de ferro comandado agora por uma multinacional alteraram significativamente a dinâmica econômica de Parauapebas, interligando o local de extração diretamente com as flutuações do preço das commodities no mercado internacional.

Durante o boom das commodities, a Vale S. A. não só intensificou suas operações no local de extração, como mobilizou a ampliação em larga escala da rede de infraestrutura logística (ver Figura 1), incluindo investimentos na construção e ampliação de estradas, ramais ferroviários e a criação de novas plantas de extração. Ao mesmo tempo, atraiu atividades de suporte à empresa, que abrangiam desde o fornecimento de grandes equipamentos operacionais a serviços de apoio de pequeno porte (por exemplo, coffee break). Dessa forma, durante um ciclo que se estendeu de 2003-2013, Parauapebas vivenciou a metáfora lefebvriana de implosão-explosão do tecido urbano: implodiu com a renovação promovida na área consolidada da cidade, com concentração de atividades e serviços urbanos e explodiu com a periferização da cidade pioneira (física e virtualmente), que passou a abranger amplas áreas do território, com uma transformação em grande 
escala do ambiente construído e natural. Esse movimento confirma a tese de Arboleda (2015b) de que as formas contemporâneas de extração de recursos estão entre as principais forças motrizes da urbanização extensiva.

\section{Figura 1 Operação logística da Vale}

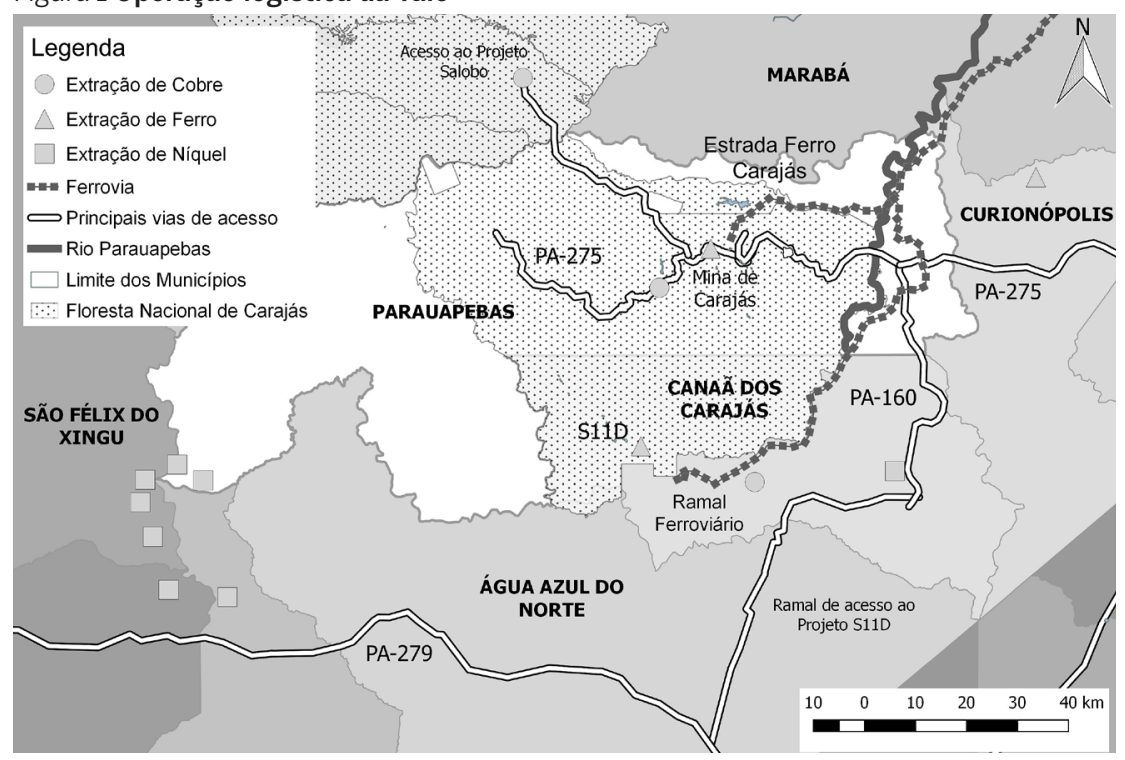

Fonte: Adaptado de Vale (2015).

Tais dinâmicas revelam a influência da grande mineração sobre o território. A coincidência na linha do tempo (ano 1997) da privatização da empresa e da criação da Floresta Nacional (Flona), correspondente à área já pleiteada pela antiga estatal (Bunker, 2007b), é uma demonstração desse poder. Além de uma política ambiental, a demarcação efetiva da Flona de Carajás garantiu a integridade da área de lavra das minas e fortaleceu a credibilidade da empresa junto aos seus acionistas. Como bem enfatizam os anúncios publicitários da Vale, o cercamento da floresta criou uma grande área de conservação de biodiversidade (Vale, 2016), mas também imobilizou e/ou modificou o acesso e o relacionamento de povos tradicionais com essas áreas face às dificuldades de concepção da própria política ambiental brasileira de matriz conservacionista, ao mesmo tempo em que liberou o avanço da ação empresarial sobre o território não protegido, sem que muita atenção fosse dada às práticas de pilhagem socioambiental desencadeadas no restante do território (Fadesp, 2016), como ocorre tipica- 
mente em sociedades capitalistas (Euclydes, 2016). Essa nova racionalidade não foi capaz de compreender a imbricação entre população tradicional e natureza viva, e desconsiderou-a a ponto de invisibilizar seus registros. Nos limites externos à Flona, estabeleceu-se a política de "terra arrasada", manifesta por meio de um extenso repertório de predação ecológica que inclui o desmonte de morros, a drenagem e assoreamento de cursos d'água, a queima ilegal de áreas de preservação ambientais e a derrubada das escassas áreas de floresta externas à Flona. Essas práticas são correntes e aceitas na região, inclusive porque foram associadas ao progresso, a despeito da legislação ambiental brasileira e da conversão de valores e práticas, criando uma situação de ruptura que pode ser mais bem detectada na esfera da vida cotidiana.

A grande mineração, ao estimular a inserção dessas novas atividades no espaço, viabilizou também relações altamente especulativas com a terra. No período de 2006 a 2008, quando houve uma valorização média anual no preço do minério de ferro em $13,3 \%$, e sua receita bruta cresceu $18,8 \%$ no mesmo período (Coelho, 2014), observou-se o início de uma vertiginosa expansão da produção de loteamentos, que resultou na duplicação da malha urbana em menos de uma década, um crescimento correspondente a 109,11\% entre os anos de 2005 e 2014 (ver Tabela 1 e Tabela 2).

Na regional, sustentada pelo agronegócio (sobretudo, a pecuária) e a produção urbana. Essa articulação teve início quando a atividade de extração de minério comandada pela Vale S.A. alcançou seus melhores resultados, combinando alta valorização das ações da empresa no mercado financeiro com um aumento crescente da produção de minério de ferro (ver Figura 2). O cenário econômico favorável à programação de grandes investimentos e a expectativa de um grande fluxo migratório de mão de obra assalariada atraiu para o Sudeste Paraense grandes incorporadoras e construtoras (WTorre, Direcional, Premium Engenharia e a Cipasa Urbanismo). Esse acontecimento resultou na inserção de novos arranjos institucionais e empresariais na região, com particular destaque para o transbordamento do capital financeiro global, antes concentrado nas interações entre a empresa de extração de recursos e o mercado internacional, para empreendimentos imobiliários, em face da capitalização das empresas imobiliárias diretamente no mercado financeiro (Fix, 2011; Melazzo, 2013; Almeida, 2016). região do Sudeste Paraense, o boom da extração mineral criou uma ponte entre a economia. 
Tabela 1 Evolução da mancha urbana no município de Parauapebas nas últimas décadas

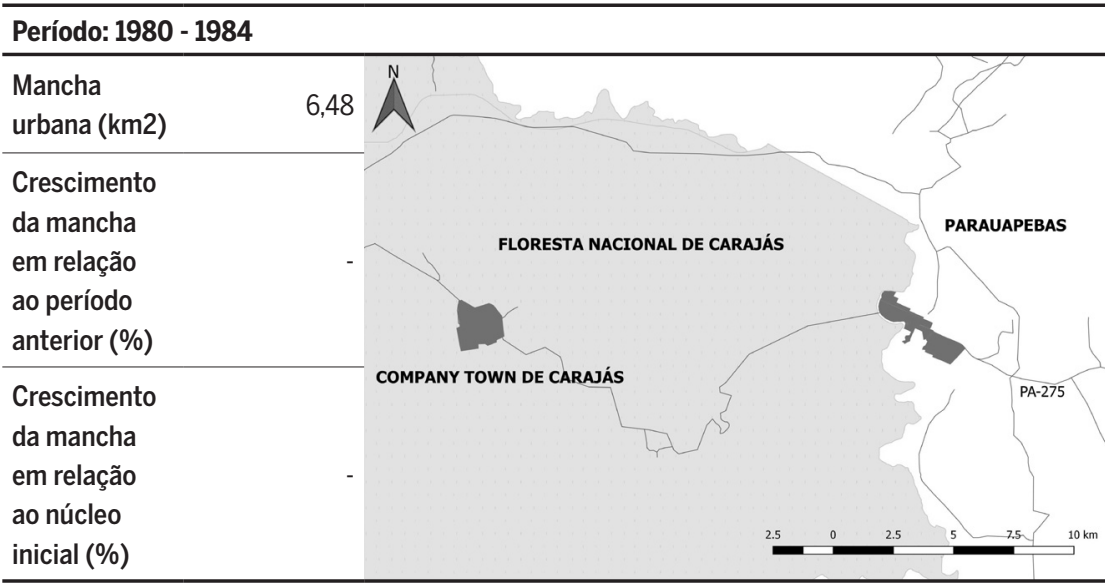

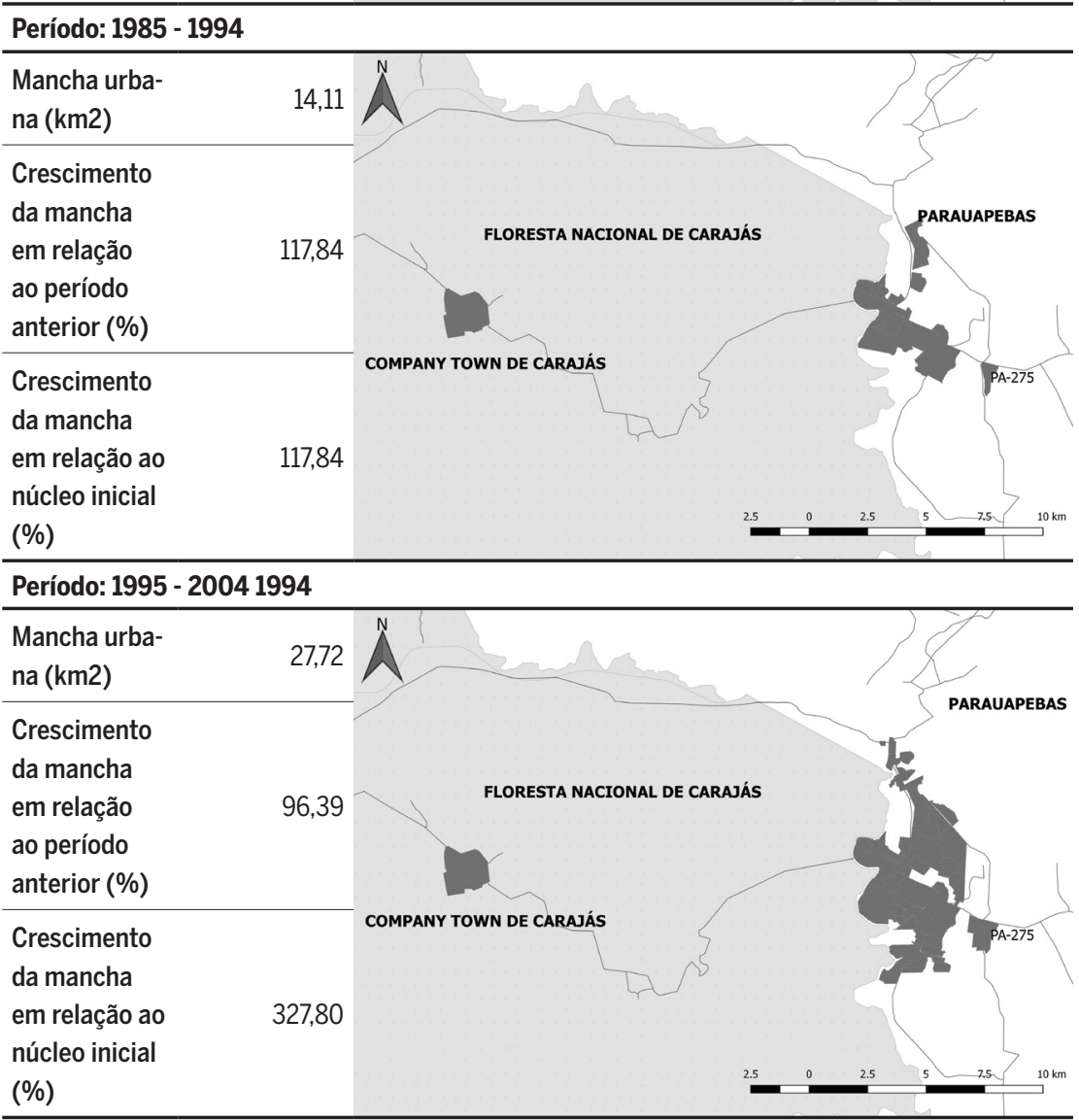

Fonte: Elaboração própria a partir de imagens do Google Earth de 1984 até 2016 (2016). 
Tabela 2 Evolução da mancha urbana no município de Parauapebas nas últimas décadas

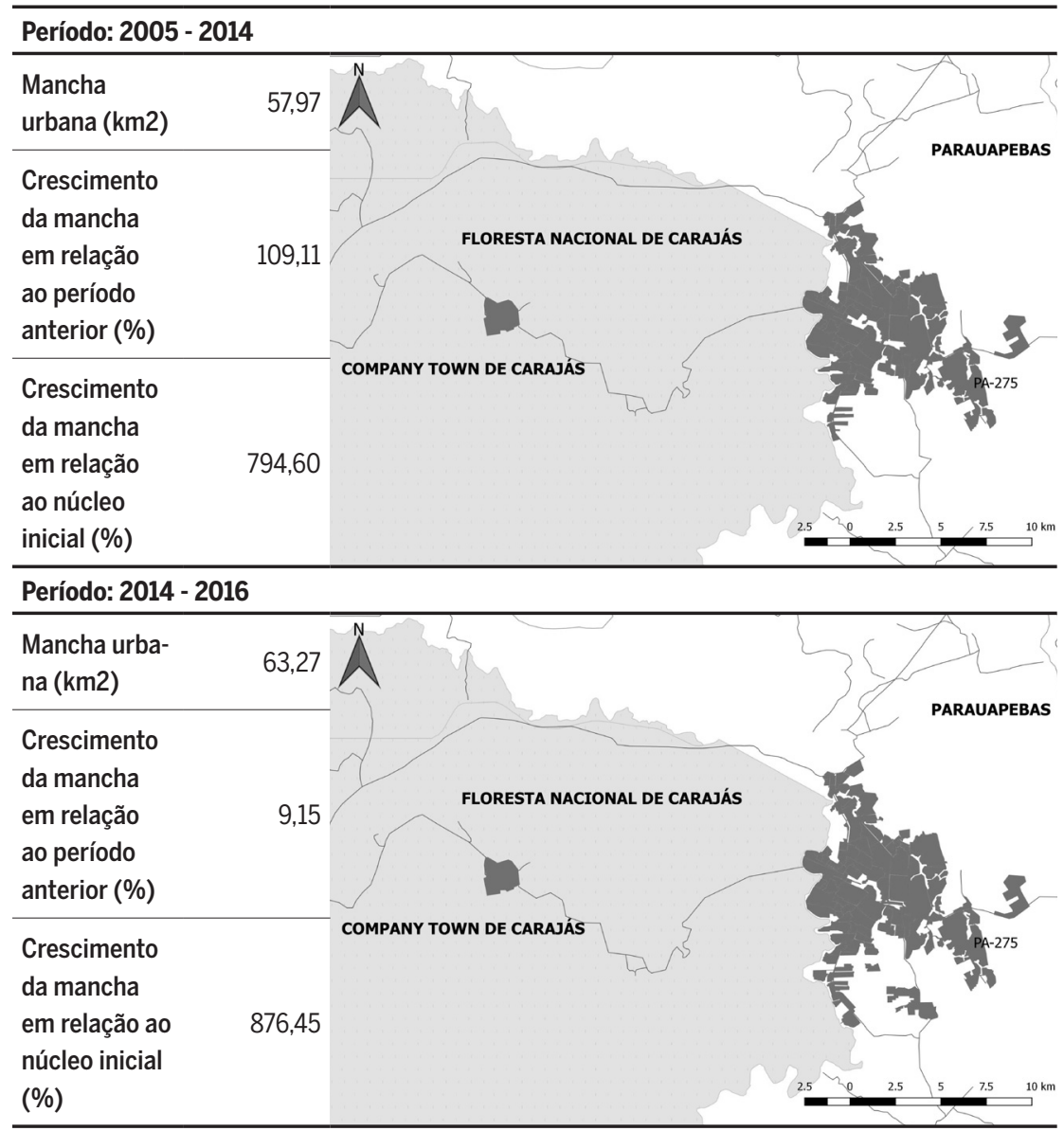

Fonte: Elaboração própria a partir de imagens do Google Earth de 1984 até 2016 (2016).

A forma de operação das construtoras e incorporadoras de grande capital não só aderiu aos interesses dos grupos empresariais da região, como impulsionou a entrada de diversos atores regionais e locais, beneficiados por incentivos governamentais em décadas anteriores no segmento imobiliário (donos de redes de supermercado, eletrodomésticos, postos de gasolina, concessionárias de veículos, empresas de mineração e agropecuária, etc.). Com a crise de 2008 e o arrefecimento da demanda chinesa na sequência, a maioria das empresas nacionais atuantes no Sudeste Paraense abandonou seus investimentos na região. Na época, as recém-criadas incorporadoras regionais lançaram grandes empreendimentos no Sudeste Paraense. A Bu- 
riti e Nova Bairros Planejados, por exemplo, produziram mais de $35 \mathrm{mil}$ lotes urbanizados somente em Parauapebas, os quais representam atualmente $30 \%$ da malha urbana.

Figura 2 Produção de minério de ferro no município de Parauapebas

\section{(em milhões de toneladas)}

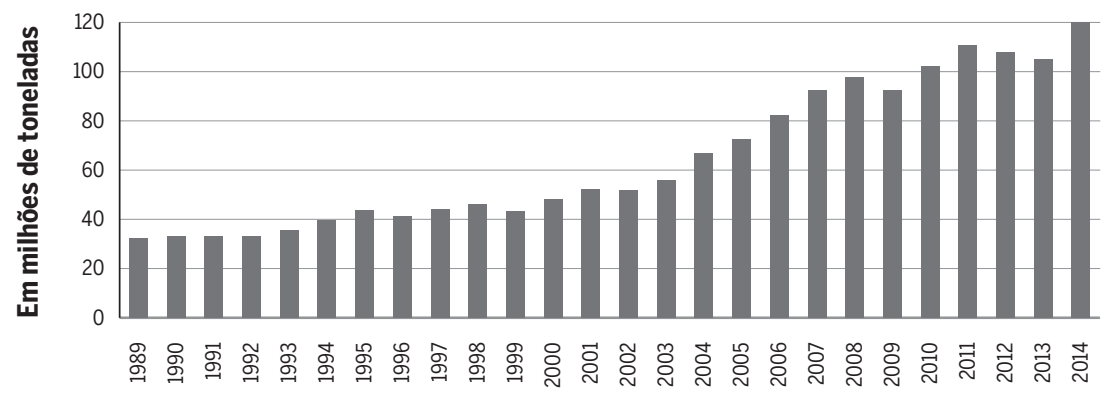

Fonte: DNPM (2015).

No decorrer de anos de pesquisas de campo ${ }^{6}$, observou-se um processo de fortalecimento das empresas regionais no mercado imobiliário, herdeiras da política de incentivos fiscais operada pela Superintendência de Desenvolvimento da Amazônia (SUDAM) desde a década de 1960. Algumas famílias e grupos empresariais, sobretudo oriundos do Centro-Sul do país, passaram a controlar imensas extensões de terras no Sul e Sudeste Paraense (Fernandes et al., 2016). Fazendo uso dessa política, amplas porções de terra da região foram convertidas em pastagens e, em outros casos, imobilizadas como possíveis portfólios de investimento para negociação futura (Schmink; Wood, 2012).

6 Missões de campo foram realizadas no âmbito dos projetos de pesquisa "UrbisAmazônia" (2013-2015), "Avaliação da Produção Imobiliária no âmbito do Programa Minha Casa Minha Vida no estado do Pará (2013-2014) e de "Avaliação dos impactos no município de Canaã dos Carajás - Eixo Economia e Cidade" (2015-2016) contemplando três cidades no Sudeste Paraense: Marabá, Parauapebas e Canaã dos Carajás. Nas cidades de Marabá e Parauapebas, as visitas de campo foram feitas durante os períodos de novembro de 2013 e março de 2014, e em Canaã dos Carajás, nos períodos de agosto e novembro de 2016. Os três primeiros campos tiveram como foco à produção de entrevistas com representantes do setor privado (sobretudo, do setor imobiliário), da administração municipal, de órgãos estaduais, lideranças comunitárias e de movimentos sociais, e com os habitantes locais; também foram feitas visitas e registros fotográficos nos bairros e distritos das cidades em estudo e pesquisa documental em bibliotecas e acervos públicos. Na última visita a campo, em Canaã dos Carajás, foram aplicados 250 questionários distribuídos em todos os setores da cidade, para melhor compreensão do perfil dos domicílios e da forma como seus habitantes têm sido afetados pelas recentes mudanças. 
Durante o boom das commodities, que coincidiu também com o período favorável à aquisição de financiamentos e subsídios do governo federal para produção de infraestrutura e habitação (2007-2011), os portfólios de terra do empresariado regional foram finalmente negociados ou mobilizados, diante da oportunidade de apropriação excepcional de renda da terra ${ }^{7}$ por seus proprietários. Diante disso, empresários e proprietários de terra regionais estabeleceram parcerias e criaram construtoras, empreiteiras e incorporadoras para atuar na região.

Nos últimos anos, algumas dessas empresas chamaram a atenção de securitizadoras e fundos de investimento, devido à dimensão dos seus empreendimentos e de seus bancos de terra (landbanks) na região. A Buriti, por exemplo, possui 135 mil lotes lançados e uma reserva de terras disponível para construção de até 200 mil lotes (Buriti, 2017). Assim, as empresas imobiliárias regionais transformaram seus empreendimentos em ativos financeiros, ampliando sua capacidade de capitalização e aquisição de crédito e entrando em contato direto com o capital financeiro globalizado. Isso tem possibilitado, até o momento, a ampliação do número de marcas e empreendimentos imobiliários e uma transformação cada vez maior do espaço urbano sob o comandado desses grupos.

O grupo Buriti, por exemplo, atua em 10 estados e em 39 cidades brasileiras, e seus sócios fundadores criaram novas marcas como a Amec Ville, a Valle, a Prime, a Costa Atlântica Empreendimentos Imobiliários, entre outras. Em 2016, na contramão da economia nacional, ampliaram seus negócios e realizaram investimentos imobiliários estimados em $\mathrm{R} \$$ 350 milhões (Jornal A notícia, 2016). A transição e/ou diversificação dos investimentos dos grupos empresariais da região em direção ao segmento imobiliário indica o papel central que a propriedade da terra assumiu com o estreitamento das conexões entre os níveis global (mercado financeiro), urbano (produção imobiliária) e o privado (reprodução da vida),

7 A renda da terra é uma categoria amplamente discutida pelo pensamento econômico desde os clássicos A. Smith, T. Malthus, D. Ricardo. Com inspiração na abordagem ricardiana, Marx procurou contribuir com a Teoria da Renda a partir de uma análise da renda da terra e da forma específica da propriedade fundiária no modo de produção capitalista (Harvey, 1980). David Harvey, em Os limites do Capital (2013 [1982]), elucida a renda da terra como o "valor" que a terra assume "capitalizada como juro sobre um capital imaginário" (Harvey, 1982, p. 451). A renda da terra não constitui a negociação de compra e venda da terra em si, mas o acesso à receitas futuras antecipadas produzidas pelos fluxos de capital e trabalho incorporados à terra. É neste sentido, que Harvey (2013[1982]) argumenta que a propriedade da terra, sob o modo de produção capitalista, tende a ser considerada um ativo financeiro puro. 
uma forma de ativo financeiro para obtenção de rendas cada vez maiores (Harvey, 1980).

\section{A produção da vida cotidiana: uma ponte entre Vallenar e Parauapebas}

Vallenar, capital da província do Vale do Huasco no Chile, é uma cidade de 228 anos, com população pouco superior a 50 mil habitantes, com localização estratégica na malha viária, o que a caracteriza como um ponto de convergência de fluxos de população, de atividades econômicas, operações logísticas e instituições políticas. Assim como em Parauapebas, suas principais atividades econômicas são a agricultura e a mineração. Parauapebas está localizada na maior província mineral do mundo, a Serra dos Carajás, possui 28 anos, e população superior a 200 mil habitantes, constitui um dos polos intermodais da região e é cortada pelas rodovias PA-275 e PA-160. Também exerce uma centralidade importante em sua região de inserção, embora a cidade de Marabá, fundada em 1913 e distante 171 quilômetros, concentre maior número de serviços, pessoas, atividades econômicas e instituições.

Parauapebas começou como uma vila de apoio à atividade de extração de minério de ferro com o início da implantação do Programa Grande Carajás (PGC) e cresceu de 3 casas para 15 mil habitantes, entre 1980 e 1985 (Bunker, 2007b). Em contraste com a ordenação industrial presente na company town de Carajás, Parauapebas cresceu aos solavancos, acompanhando o ritmo ditado pela produção de minério de ferro e de seu estímulo ao capital rentista ${ }^{8}$ e/ou produtivo atuante em seu território. As ações públicas e privadas transformaram rapidamente a densa floresta e o modo de vida da rarefeita população que habitava a Serra dos Carajás antes do projeto. Incrustada no interior da floresta amazônica, mesmo com a participação da iniciativa privada, a operação da mina exigiu um amplo esforço do Estado brasileiro para viabilizar a infraestrutura logística necessária para o início da produção e exportação do minério. Estradas, ferrovia, porto e novos serviços foram mobilizados e uma cultura urbana-industrial foi introduzida no território anteriormente isolado.

8 Em síntese, o capital rentista constitui o capital que rende juro sobre o capital monetário (Harvey, 2013 [1982]). 
Em contraste, apesar dos dois séculos a mais de existência, Vallenar experimentou só recentemente a intensificação das transformações urbanas associada à chegada de grandes investimentos estrangeiros voltados à extração de recursos. Mas assim como em Parauapebas, a grande mudança no ritmo e escala do processo de urbanização aconteceu na última década, quando a população da cidade chilena passou a vivenciar a urbanização extensiva não só em termos de mudanças no ambiente construído, como em seu modo vida. Em ambos os casos, houve uma modernização do espaço, caracterizada por mudanças nos padrões de consumo, estimulando a população a consumir diretamente os produtos da modernidade, sobretudo diante da chegada das grandes redes do varejo. Em Parauapebas, esse movimento foi plenamente viabilizado a partir do espraiamento da malha urbana (hoje, 8 vezes maior do que o núcleo pioneiro em 1984), por meio da inauguração de shoppings centers, condomínios de luxo, loteamentos urbanizados, lojas de varejo, hotéis e centros comerciais, numa escala e velocidade muito superior ao movimento experimentado nas décadas anteriores.

Assim como no Chile, a intensificação dos fluxos de capital se traduziu em distorções na economia local, durante o período de boom das commodities. Nesse contexto, o setor público e o setor privado em coalizão alinharam a produção urbana às flutuações no preço do minério. $\bigcirc$ que representou, para o município paraense, a viabilização de obras públicas (novas estradas, elevados, sedes administrativas, escolas, centro de abastecimento, praças, etc.), bem como uma massiva produção de habitação, derivada de fórmulas do urbanismo global (Muxi, 2004). Em Parauapebas, até 2013, os preços de aluguel e de venda de imóveis urbanos eram, em média, cinco vezes maiores do que os preços praticados atualmente (pesquisas de campo, 2014). A queda no preço do minério de ferro criou um "efeito cascata" na economia local. A redução dos investimentos da mineradora transnacional na esfera produtiva refletiu em um aumento no número de demissões e na redução dos benefícios concedidos aos funcionários da empresa. Entre os benefícios extintos figurava o auxílio moradia, cujo corte teve impacto direto sobre o mercado fundiário. Durante o período de vigência do auxílio moradia, o montante correspondente ao mesmo tornou-se o parâmetro mínimo para o cálculo dos preços de aluguéis na cidade.

Assim como em Vallenar, a euforia impulsionada pelo ciclo de valorização do minério no mercado global atraiu cadeias de varejo, que se tornaram uma âncora para a integração da população ao mundo de consumo. 
A urbanização extensiva associada ao frenesi da extração de recursos introduziu rapidamente na dimensão da vida diária diversos impulsos da globalização capitalista contemporânea, desvalorizando antigas formas de produção ou mesmo os produtos locais. Em um território da fronteira amazônica diretamente conectado ao mercado globalizado, um desses símbolos assimilados pela população foi a Black Friday, um dia excepcionalmente dedicado ao consumo conspícuo criado pelos norte-americanos, no qual uma multidão de pessoas aguarda desde o dia anterior a abertura das redes de varejo locais e até o fechamento dos portões um movimento intenso é registrado nas lojas.

Em paralelo à intensificação da produção da cidade ${ }^{9}$, houve a implantação da principal rede varejista presente do Norte-Nordeste, o Grupo Mateus, criado em 1991, como desdobramento da trajetória de um garimpeiro da Serra Pelada, que ilustra um caso curiosamente conectado ao mercado de commodities, primeiro ao ouro e, posteriormente, ao agronegócio. Hoje a rede atua em diversos segmentos (atacado, eletrônico, produtos farmacêuticos, etc.), é uma das maiores redes regionais, possui 17 mil funcionários e mantém 58 empreendimentos. Arboleda (2015a) argumenta que a presença de grandes redes de varejo tanto é uma expressão da lógica de urbanização em contextos não metropolitanos e de grande afluxo de investimentos, quanto reforça uma tendência global, iniciada na década de 1990, de expansão de redes de varejo com sistemas de crédito próprios, como consequência da redução do papel do Estado na provisão de bens coletivos e intensificação das trocas internacionais. Na esteira desses acontecimentos, em 2011, o Grupo Mateus, em parceria com o Banco Bradesco, lançou no mercado seu próprio cartão de crédito e criou um sistema em que seus funcionários consomem na própria rede varejista os benefícios da empresa como o vale-alimentação, corroborando a emblemática formulação kaleckiana de que "os capitalistas ganham o que gastam e os trabalhadores gastam o que ganham". Tanto o movimento de extensão do tecido urbano de Vallenar quanto de Parauapebas confirmam a argumento de Arboleda (2015a), sobre as novas paisagens financeiras. Segundo o autor, a expan-

9 Entendida como espaço socialmente construído, simultaneamente tecido pela produção física, isto é, da construção de prédios, casas, ruas, redes de transporte coletivo, estradas, rodovias, espaços públicos, conjuntos habitacionais, condomínios, etc., e também, por meio das representações sociais, que se projetam sobre o espaço da cidade, pela ação de instituições, de agentes urbanos, da população e de outros organismos sociais. Ver, a respeito, Henri Lefebvre (2008 [1970]); David Harvey (2005); Mark Gottdiener (1997); entre outros. 
são de crédito via redes de varejo reflete um movimento do capitalismo global, em que empresas não-financeiras se articulam cada vez mais com processos financeiros, independente do sistema bancário. Em acordo com as dinâmicas recentes, também se observa um movimento concomitante de inserção no sistema de crédito de indivíduos e famílias em situação de vulnerabilidade, especialmente mutuários socialmente marginalizados, sub-remunerados, terceirizados ou empregados temporariamente (Harvey, 2011 [2010]).

O Programa Minha Casa Minha Vida (PMCMV), por exemplo, tornou evidente a ampliação do acesso ao crédito aos segmentos mais frágeis da população, em termos financeiros, na medida em que o PMCMV era acompanhado pelo programa Minha Casa Melhor. Este último financiava a aquisição de móveis, eletrodomésticos e eletroeletrônicos aos mutuários do PMCMV. Se, de um lado, o programa governamental permitiu que amplos segmentos da população tivessem acesso à habitação e ao consumo de produtos domésticos, por outro, tornou grande parte dessa população sujeita ao endividamento, devido à permanência de seus baixos rendimentos e da situação informal ou instável de suas ocupações, tal fato decorrente da incapacidade das atividades econômicas modernizadoras absorverem os contingentes de trabalhadores e/ou de migrantes oriundos do universo rural/camponês que historicamente se constituíram em excluídos urbanos. Como conclui a pesquisa de Arboleda (2015a, p. 9):

A configuração e reconfiguração das paisagens de crédito nos permite visualizar a natureza eminentemente desigual dos processos de urbanização extensiva porque os tipos de atores financeiros que se seguiram à chegada de mineração transnacional são precisamente os que se especializam em consumidores de "alto risco".

Nas pesquisas de campo realizadas entre 2012 e 2016 no Sudeste Paraense, a narrativa de endividamento e da devolução de bens, inclusive imóveis, foi frequente, sobretudo em 2016, quando a recessão econômica da indústria de extração foi mais claramente sentida pela população, através do aumento no número de demissões diretas ou indiretamente associadas à mineração. Apesar do extensivo processo de produção habitacional, já ocorre esvaziamento dos loteamentos urbanizados destinados para as faixas de renda média e baixa, e transferência de famílias pobres para áreas da cidade sujeitas ao risco ou ambientalmente vulneráveis.

Há distinções essenciais entre o projeto chileno de Pascua Lama e o da Serra de Carajás. O primeiro, mais recente, configura uma área de 
extração adquirida pela empresa canadense Barrick Gold no mesmo ano de privatização da Vale e, portanto, desde o princípio opera dentro do marcos neoliberais. $O$ projeto de Carajás, além de somar três décadas de funcionamento, experimentou um breve período coordenado por uma empresa estatal, que possibilitou certa resistência à livre ação da iniciativa privada e do capital financeiro global em seus primeiros anos, no âmbito de um projeto nacional-desenvolvimentista. Essa diferença, entre o perfil de gestão empresarial estatal versus privada, pode bem ser observada no próprio território do Sudeste Paraense. A ação da empresa estatal, CVRD, na Serra dos Carajás possibilitou a consolidação de uma infraestrutura urbana, ainda que bastante frágil, que garantiu a criação de algumas amenidades na produção do espaço urbano, inexistentes em projetos mais recentes realizados pela Vale, como é o caso do S11D, maior projeto de extração de minério de ferro da Vale, localizado a 60 quilômetros de Parauapebas.

Em comum, ambos os projetos de mineração, desde sua gênese, são derivações de interesses localizados a milhares de quilômetros de distância (Santos, 1986), inseridos em espaços incompletamente organizados e seletivos, onde o Estado e sua ação "planejada" têm sido mais favoráveis ao nível global, onde operam as multinacionais inseridas no circuito global de acumulação, do que em relação às demandas diárias da população. Tais geografias hoje expressam mais claramente a inter-relações entre níveis e, um exemplo disso, é o processo de expansão das relações financeiras em esferas que anteriormente não estavam sujeitas a sua influência, como é caso do setor imobiliário em Parauapebas. Esta nova paisagem financeira em formação na fronteira amazônica conecta dialeticamente práticas e mecanismos financeiros globais, urbanos e locais. $\bigcirc$ lado perverso do processo de urbanização extensiva se revela na, nem sempre evidente, expansão dos processos de pilhagem socioambiental.

Como exemplo disso, destaca-se um emblemático projeto habitacional, lançado pela prefeitura de Parauapebas em parceria com a construtora paulista Qualyfast, especialista no desenvolvimento de projetos para o PMCMV, durante o frenesi imobiliário alavancado pelo programa. A construção do Residencial Alto Bonito no Morro do Chapéu foi bastante representativa do poder exercido pelos níveis intermediários e globais (o Estado, as instituições, o grande capital) sobre o espaço de vida da população. O projeto foi um duplo golpe sobre o nível local. Tanto sobre a popu- 
lação pobre que havia ocupado o Morro e foi duramente retirada do local através do poder da polícia, justificado pela aplicação do código florestal (o morro se constitui em uma Área de Preservação Permanente urbana); quanto sobre o Morro, cujo argumento de preservação foi solapado em seguida com o corte e total remoção da vegetação existente para atendimento dos parâmetros do empreendimento habitacional. O novo conjunto habitacional, um complexo formado por 34 blocos de 7 apartamentos, reproduziu a fórmula global do condomínio, completamente dissonantes da prática e do modo de vida da população residente no local, inviabilizando sua permanência e usufruto dos investimentos em habitação. Por outro lado, a nova tipologia adequou a área aos empreendimentos circundantes, produzidos para outros segmentos de renda (Melo; Cardoso, 2014). O caso do Morro do Chapéu evidencia a natureza eminentemente desigual da urbanização capitalista, sobretudo quando se permite que a iniciativa privada atue livremente, priorizando a redução dos custos e ampliação de seus lucros. No limite, o projeto representou um movimento de operacionalização e abertura de novas frentes de expansão para o capital a partir de um processo de gentrificação ${ }^{10}$ e modernização espacial. $\bigcirc$ afastamento da população pobre e migrante das áreas urbanas consolidadas constitui um impacto indireto do projeto de mineração face à grande expectativa de captura do capital circulante por meio da renda da terra durante a fase bem sucedida da extração de minério na região.

Os relatos contidos neste texto ilustram a mineração como uma dinâmica subjacente à transformação e expansão recente do tecido urbano no Sudeste Paraense, vínculo intrinsecamente relacionado às mudanças no capitalismo e, sobretudo, à proeminência assumida pelo capital financeiro sobre as atividades produtivas ao longo das últimas décadas. Tal processo permitiu ao mercado de capitais atuar em diversos setores da economia. É neste sentido que o fenômeno da financeirização constitui em si "a construção ampliada e diversificada destes canais por onde passam fluxos de mais-valor, lucros e renda advindos de fontes diversificadas e difusas" (Magalhães, 2015, p. 129). Este protagonismo das finanças, evidente em

10 A gentrificação corresponde a um fenômeno comum em processos de renovação urbana, no qual ocorre retirada forçada, ou não, de habitantes de baixo poder aquisitivo de uma determinada área ou bairro em função da entrada de novos investimentos privados, públicos ou, como acontece com frequência, público-privados (as chamadas PPPs). Ver, a respeito, Jacobs (2011); Hall (2011); Muxi (2004); entre outros. Para uma perspectiva brasileira ver Fix (2001); Valença (2014). 
atividades orientadas à exportação de commodities como o minério de ferro, alavancou a entrada maciça de investimentos nos locais de extração durante a última década, devido à demanda mundial por matérias-primas inserida no boom das commodities. Nesse processo, os países latino-americanos se tornaram atraentes tanto por abrigarem grandes reservas minerais, quanto por apresentarem estruturas regulatórias favoráveis aos investimentos transnacionais. Assim, ao mesmo tempo em que a inversão de capital em tais regiões impulsionou a produção de infraestrutura logística, energética e a intensificação das operações de extração de minério, também fez com que novos investidores financeiros em busca de oportunidades de investimentos ampliassem suas atuações e passassem a se inserir em novos mercados, a exemplo do imobiliário e de terras (Nunes, 2015). Sob essa perspectiva, a financeirização invade os domínios da produção urbana e, no caso brasileiro que é marcado por uma estrutura fundiária historicamente concentrada, oferece um estímulo extraordinário para que grandes proprietários de terras passem a operar no setor imobiliário e terciário e a criem vínculos com o mercado de capitais. A adoção dessa lógica tornou a produção da cidade um negócio, apoiado em coalizões e no know how internacional (financiamento, planejamento dos empreendimentos, securitização), associado às demandas por habitação e serviços urbanos geradas pelo ritmo acelerado de investimentos da mineração. As operações financeiras de capitalização das empresas mineradoras viabilizam não só a ampliação exponencial de sua produção, mas geram a condições para que outros setores, também apoiados pelo mercado financeiro, explorem os ambientes afetados pela atividade extrativa.

\section{6 ( $\mathrm{Re}$ )invertendo prioridades: primeiro o cotidiano, o urbano, depois o global}

O objetivo central deste artigo foi evidenciar - a partir de uma leitura comparativa entre a atuação de duas grandes indústrias de extração mineral localizadas em países da América do Sul, uma na região de Pascua Lama, nos Andes chilenos, e o outra na Serra dos Carajás, na Amazônia Oriental brasileira - como os espaços de extração de recursos naturais têm se configurado como peças-chave para a compreensão das atuais dinâmicas do capitalismo. Em ambos os casos, a urbanização foi colocada a serviço de in- 
teresses econômicos e da captura de capital excedente, que transborda de atividades produtivas e cada vez mais da esfera não-produtiva comandada pelo circuito financeiro, resultando na transposição do ritmo das dinâmicas do circuito global de troca diretamente para o espaço dessas cidades.

Apesar dos pontos de tangência, a investigação sobre Parauapebas evidencia importantes especificidades em relação à operação do capital na fronteira amazônica, onde se observa que as inter-relações entre os níveis da realidade social se configuram de tal forma, que somente um número limitado de atores (grandes proprietários ou controladores da terra) beneficia-se dos transbordamentos de capital, articulados à operação da empresa mineradora por meio da expropriação de renda da terra, tanto dos segmentos articulados ao nível global, como através da espoliação da população mais vulnerável, que permanece distante dos benefícios associados à mineração. Entretanto, é claro que os grupos sociais excluídos (representados seja por população original, imigrantes das fases de colonização ou novos imigrantes) se constituem em segmento estratégico para aumentar as margens de lucro dos atores inseridos nos níveis global e intermediário. A formação recente de Parauapebas gerou uma forte polarização dos grupos sociais, entre os que trabalham para a mineração direta ou indiretamente, e os que estão excluídos, de modo a criar um forte controle da mineradora e dos proprietários de terra sobre diversos elos dos arranjos produtivos praticados na região. Isso difere do caso chileno onde os dois séculos de história permitiram um ritmo mais lento e estável da transformação impulsionada pela mineração. Parauapebas era uma "página em branco", que carecia de institucionalidades e facilitava a usurpação violenta e a invisibilização de atores sociais.

Mesmo as tentativas de fortalecimento da geração de renda para extrativistas realizadas pela Vale S.A. reduzem os coletores de sementes de jaborandi, por exemplo, a simples fornecedores de uma matéria-prima rara e lucrativa para os agentes localizados no topo da cadeia produtiva (a indústria de fármacos e cosméticos). A conversão do trabalho dos extrativistas como parte de um arranjo produtivo de alcance global coloca em risco a própria continuidade da atividade. Isso porque, o esforço físico e as dificuldades exigidas pelo trabalho, o processo de envelhecimento da população coletora e o desinteresse das novas gerações em participar da atividade dificultam a permanência do extrativismo sustentável em Carajás. Além disso, o baixo lucro associado à venda do produto, o desconheci- 
mento da população urbana (migrante) sobre a existência e a importância da preservação do extrativismo na Flona e, por fim, a não incorporação de conhecimento técnico, inovativo e tecnológico pelos grupos sociais diretamente envolvidos com coleta invisibiliza as expectativas de construção de uma matriz urbana alternativa (a do urbano-natural).

A prematura aniquilação dessa possibilidade desperdiça a oportunidade de: empoderar o habitante local, enraizar uma cadeia produtiva ambientalmente compreensiva na região, conectar a cultura urbana a uma matriz de conhecimento tradicional, incentivar o desenvolvimento de novas atividades produtivas com base na biodiversidade e retirar do campo cego ${ }^{11}$ os grupos socialmente excluídos (nativos e migrantes pobres) que são os verdadeiros portadores do potencial para geração de um nova forma de desenvolvimento, genuína e autônoma, para a região Amazônica.

Enquanto isso, em Parauapebas, as dinâmicas globais ligadas ao mercado financeiro, transcenderam a exportação de commodities e se apropriaram intensamente da produção do espaço urbano. Nos últimos anos, atores globais ligados ao mercado financeiro têm se aliado a atores regionais e produzido um processo de urbanização extensiva intensificado durante o boom das commodities. Em Parauapebas, esta expansão é observada em seu aspecto físico através surgimento de um número excepcional de loteamentos urbanizados, e do ponto de vista social através de alterações substanciais no modo de vida da população. A incorporação de padrões de consumo modernos tende a dissolver não somente antigos hábitos presentes na vida privada de seus habitantes, mais também arranjos coletivos importantes do ponto de vista econômico, social e cultural, como é o caso das atividades extrativistas, das feiras e dos espaços de lazer associados à natureza (rios, igarapés, parques). Se, por um lado, as dinâmicas em curso em locais de extração de recursos naturais evidenciam uma ponte cada vez próxima entre atores globais, intermediários e locais; por outro, essas relações se projetam através de um conjunto amplo e diverso de contradições sobre espaço da vida da população, principalmente de sua parcela mais vulnerável.

Nos casos chileno e brasileiro à presença do capital estrangeiro e ação 11 conceito lefebvriano (2008 [1970]) se refere às distorções criadas por representações ideológicas e institucionais que não permitem que certos processos socioespaciais em formação sejam reconhecidos em sua totalidade. Tais processos são apreendidos de forma fragmentária, deformada, especializada, uma vez que são observados através da lente monolítica do paradigma urbano-industrial. 
do Estado orientada em favor de estratégias neoliberais, estimularam a atração de grandes fluxos de capital para os locais de extração. Essa convergência alavancou a expansão prematura do ambiente construído e a intensificação de processos de especulação com a terra, cada vez mais conectados à dinâmicas globais de circulação de capital. Se no caso chileno esta trajetória foi impulsionada através de medidas de desregulamentação financeira, em Parauapebas, a ausência de regulação e mesmo de informação sobre a potência desses fenômenos favoreceu diversas manifestações de acumulação primitiva.

Com o arrefecimento da demanda chinesa por commodities no nível global, grandes mudanças têm sido observadas na região da Serra dos Carajás. A próspera cidade mineradora de alguns anos atrás já enfrenta um período de recessão com influência direta dos ajustes financeiros da Vale S.A., que incluem: a transferência e a demissão de funcionários da companhia e terceirizados; a paralisação de plantas industriais, o encerramento de serviços e atividades de apoio à empresa e aos funcionários; diminuição drástica no preço dos imóveis e na produção de novos empreendimentos. Paradoxalmente, no nível da vida cotidiana, nota-se um movimento de reestruturação urbana. Em contraste com a tendência econômica, a redução do custo de vida tem possibilitado a permanência e inserção do migrante pobre na cidade. Pequenos comércios e atividades informais têm surgido e estão se fortalecendo. E diversas estratégias de sobrevivência começam a despontar como alternativas (hortas urbanas, coleta de semente, artesanato, etc.) ao estreito mercado formal definido pela empresa mineradora. Também têm se intensificado o uso e a realização de atividades no espaço coletivo, em praças, parques e espaços livres, a exemplo de uma imensa área de lazer construída por uma das construtoras nacionais atuantes em Parauapebas, a qual tem permanecido acessível à população enquanto os lotes no entorno não são ocupados. As manifestações coletivas no espaço público têm sido mais frequentes, inclusive àquelas de orientação política dirigidas ao Estado, à mineradora e às próprias empresas imobiliárias, com objetivo colocar na pauta do dia às demandas mais imediatas da população. Uma dessas conquistas foi a regularização, ainda que deficiente, do transporte coletivo.

Conclui-se que existe uma janela de oportunidade aberta a uma nova matriz urbana em contraste, com as limitadas possibilidades oferecidas pela matriz urbano-industrial, até hoje assumida como hegemônica. Como 
preconizado por Monte-Mór, uma nova práxis urbana se apresenta no horizonte, associada a uma matriz urbano-natural, que recupera a conexão entre pessoas e meio físico e dá aos excluídos de outrora visibilidade e protagonismo. Face à forte dependência da cidade da mineração, esta seria uma possibilidade de redenção e mudança de curso, com mudança do padrão da pilhagem e transformação intensiva da natureza para o enraizamento genuíno de trajetórias invisíveis ou recusadas até então, que tornam o diferente aceito, seja ele indígena, camponês, extrativista ou artesão. A inclusão desses grupos por meio do reconhecimento da natureza viva como insumo para a subsistência de parte da população é uma alternativa para a construção de uma identidade cultural para o Sudeste Paraense com base na diversidade constituída historicamente, não dependente apenas do grande capital.

Face às observações das reações na esfera local, sustenta-se a necessidade de (re)inversão da dinâmica urbana atual, dos interesses de acionistas, gestores corporativos, especuladores e rentistas (com total determinação da esfera global), para a esfera local, que sequer é visível aos olhos dos grandes players globais. Propõe-se que o urbano-natural seja incorporado à urbanização extensiva, como naturalização extensiva, que articula cidade, campo e natureza, para garantir a reprodução da vida e o aprofundamento da cidadania responsiva à diversidade da esfera de vida local.

\section{Referências}

ALMEIDA, Renan. Os efeitos assimétricos da crise no setor de construção civil. 2016. Disponível em: <http://brasildebate.com.br/os-efeitos-assimetricos-da-crise-no-setor-de-construcao-civil/>. Acesso em: 05 de maio de 2017.

ARBOLEDA, Martín. Financialization, totality and planetary urbanization in the Chilean Andes. Geoforum, [s.1.], v. 67, p. 4-13, dez. 2015a. Elsevier BV. DOI: 10.1016/j.geoforum.2015.09.016. Disponível em: <http://api.elsevier.com/content/article/PII:S00167185 1530052X?httpAccept=text/xml>. Acesso em: 08 fev. 2016.

ARBOLEDA, Martín. Spaces of extraction, metropolitan explosions: planetary urbanization and the commodity boom in Latin America. International Journal of Urban and Regional Research. v. 40, n. 1, p. 96-112, nov. 2015. DOI: http://dx.doi.org/10.1111/1468-2427.12290.

BRANDÃO, Carlos. Pactos em Territórios: escalas de abordagem e ações pelo desenvolvimento. Organizações \& Sociedade (Impresso), v. 15, p. 145-157, 2008.

BRENNER, Neil. Introduction: urban theory without an outside. In: BRENNER, Neil (Ed.), Implosions/Explosions: Towards a Study of Planetary Urbanization. Jovis: Berlin, 2014. 
BRENNER, Neil (Ed.). Implosions/Explosions: Towards a Study of Planetary Urbanization. Berlin: Jovis, 2014.

BRENNER, Neil; SCHMID, Christian. The 'Urban Age' in Question. International Journal of Urban and Regional Research. v. 38, n. 3, p. 731-755. 2014. DOI: 10.1111/1468-2427.12115

BRENNER, Neil; SCHMID, Christian. Towards a new epistemology of the urban? City, [s.1.], v. 19, n. 2-3, p. 151-182, abr. 2015. Informa UK Limited. DOI: http://dx.doi.org/10.1080/ 13604813.2015.1014712.

BUNKER, Stephen. Da castanha-do-pará ao ferro: Os múltiplos impactos dos projetos de mineração na Amazônia brasileira. In: COELHO, Maria Célia N.; MONTEIRO, Maurílio de Abreu. Mineração e Reestruturação Espacial na Amazônia. Belém: NAEA, 2007a, p. 105-137.

BUNKER, Stephen. Os Fatores Espaciais e Materiais da Produção e os Mercados Globais. In: COELHO, Maria Célia N.; MONTEIRO, Maurílio de Abreu. Mineração e Reestruturação Espacial na Amazônia. Belém: NAEA, 2007b. p. 65-96.

BURITI Empreendimentos. 2017. Disponível em: <http://www.buritiempreendimentos. com.br/home/>. Acesso em: 12 fev. 2017.

EUCLYDES, Ana Carolina. A Hipótese otimista: dialética e utopia das áreas verdes, das áreas protegidas e da trama verde e azul. 2016. 270 f. Tese (Doutorado) - Curso de Arquitetura e Urbanismo, Escola de Arquitetura da Universidade Federal de Minas Gerais, UFMG, Belo Horizonte, 2016.

FADESP. Avaliação dos Impactos no Município de Canaã dos Carajás Economia e Cidade. Belém, 2016. $2 \mathrm{v}$.

FERNANDES, Danilo. et al. A formação das elites na amazônia: diversidade estrutural e estratégias de desenvolvimento regional no século XX. Relatório de Pesquisa (Projeto Edital Universal 2013), 2016.

FIX, Mariana. de A. Parceiros da exclusão. São Paulo: Boitempo, 2001.

FIX, Mariana. de A. Financeirização e transformações recentes no circuito imobiliário no Brasil. 236 f. Tese (Doutorado). Curso de Desenvolvimento Econômico. Unicamp, Campinas. 2011

FONTEVECCHIA, Agustino. Barrick Gold Fined \$16M For Environmental Problems At \$5B Pascua Lama Project In Chile. 2013. Disponível em: <https://www.forbes.com/sites/afontevecchia/2013/05/24/chilean-government-fines-barrick-16m-for-environmental-damage-in-pascua-lima-mine-stock-halted/\#4f8b538523e4>. Acesso em: 24 maio 2013.

GONZALES, Jenny. Desastre da barragem de Mariana completa um ano e leva a processos judiciais. The Intercept Brasil. São Paulo, p. 1-8. 8 nov. 2016. Disponível em: <https://theintercept.com/2016/11/08/desastre-da-barragem-de-mariana-completa-um-ano-e-conduz-a-processos-judiciais/>. Acesso em: 12 maio 2017.

GOTTDIENER, Mark. A Produção social do espaço urbano. São Paulo: Editora da Universidade de São Paulo, 1997.

HARVEY, David. A produção capitalista do espaço. São Paulo: Annnblume, 2005.

HALL, Peter. Cidades do amanhã. São Paulo: Perspectiva, 2011.

HARVEY, David. Enigma do capital e as do capitalismo. São Paulo: Boitempo, 2011 [2010].

HARVEY, David. Limites do capital. São Paulo: Boitempo, 2013[1982]. 
JACOBS, Jane. A natureza das economias. São Paulo: Beca, 2001.

JACOBS, Jane. Morte e vida nas grandes cidades. São Paulo: Martins Fontes, 2011.

JORNAL A NOTÍCIA. Na contramão da crise econômica: Investimento imobiliário vai injetar r\$ 350 Milhões na economia Paraense. Disponível em: <http://www.an10.com.br/noticias/7070>. Acesso em: 05 ago. 2016.

LEFEBVRE, Henri. A Revolução Urbana. Belo Horizonte: UFMG, 2008 [1970].

MAGALHÃES, Felipe. O neoliberalismo e a produção do espaço na metrópole: subjetividades, insurgências e redes na economia política da urbanização contemporânea. 2015. $271 \mathrm{f}$. Tese (Doutorado) - Curso de Geografia, Ufmg, Belo Horizonte, 2015.

FEARNSIDE, Philip. Dams in the Amazon: Belo Monte and Brazils Hydroelectric Development of the Xingu River Basin. Environmental Management, London, v. 1, n. 38, p. 16-27, 01 jul. 2006. Disponível em: <https://link.springer.com/article/10.1007/s00267-005-0113-6>. Acesso em: 12 maio 2017.

MELAZZO, Everaldo. Estratégias fundiárias e dinâmicas imobiliárias do capital financeirizado no brasil. Mercartor, Fortaleza, v. 12, n. 2, p. 29-40, set. 2013.

MELO, Ana Carolina; CARDOSO, Ana Cláudia. Cidade para quem? O descompasso entre políticas ambientais e urbanas na periferia do capitalismo. Cadernos de Arquitetura e Urbanismo, Minas Gerais, v. 21, n. 29, p. 82-103, 2014. Disponível em: http://periodicos. pucminas.br/index.php/Arquiteturaeurbanismo/article/view/13076. Acesso em: 19 janeiro 2017.

MELO, Ana Carolina. Modernização e transformações recentes nos processos intra-urbanos no Sudeste do Pará. Dissertação (Mestrado em Arquitetura e Urbanismo), Faculdade de Arquitetura e Urbanismo, Universidade Federal do Pará, Belém, 2015.

MONTE-MÓR, Roberto. Urbanização extensiva e lógicas de povoamento: um olhar ambiental. Território, globalização e fragmentação. São Paulo: HUCITEC/ANPUR, 1994.p. 169-181.

MONTE-MÓR, Roberto. Gênese e estrutura da cidade mineradora. Texto para discussãon $n$. 164, CEDEPLAR, FACE, UFMG, 2001

MONTE-MÓR, Roberto. Teorias e Práticas Urbanas, condições para a sociedade urbana. Belo Horizonte: C/Arte, 2015. p. 55-70.

MUXÍ, Zaida. Ciudad Global. Barcelona: Gustavo Guili, 2004.

PECK, Jamie. Cities beyond Compare? Regional Studies, [s.1.], v. 49, n. 1, p. 160-182, 17 dez. 2014. Informa UK Limited. DOI: http://dx.doi.org/10.1080/00343404.2014.980801.

SANTOS, Milton. O trabalho do geógrafo no terceiro mundo. São Paulo: Hucitec, 1986.

SANTOS, Milton. Espaço dividido: os dois circuitos da economia urbana dos países subdesenvolvidos. São Paulo: Edusp, 2000 [1974].

SCHMINK, Marianne; WOOD, Charles. Conflitos sociais e a formação da Amazônia. Belém: Edufpa, 2012.

VALENÇA, Márcio Morais (Org.). Cadernos Metrópole (Gentrificação na Cidade Contemporânea), v. 16, n. 32, Semestral. Rio de Janeiro, 01 nov. 2014. Disponível em: <https://revistas. pucsp.br/index.php/metropole/issue/view/1333/showToc>. Acesso em: 12 maio 2017. 


\section{Sobre os autores}

Ana Carolina Campos de Melo - carolmelo.08@gmail.com

Universidade Federal do Pará

Ana Cláudia Duarte Cardoso - aclaudiacardoso@gmail.com

Universidade Federal do Pará

Agradecemos ao apoio do CNPq, pela bolsa PQ e a FAPESPA (Fundação Amazônia de Amparo a Estudos e Pesquisas) pela bolsa de doutorado concedida ao PPGE/UFPA.

\section{Sobre o artigo}

Recebido em 10 de março de 2017. Aprovado em 26 de maio de 2017. 